\title{
Legal Protection for Buyers in Car Sale-Purchase Transaction on Indent Basis
}

\author{
Tineke Indriani ${ }^{1}$ \\ \{tinekeindrianish@gmail.com\}
}

${ }^{1}$ Doctoral Students of Law Science of Jayabaya University, Indonesia

\begin{abstract}
The study aims to discuss about legal protection for buyers (car indenters) considering that in new car sale-purchase transactions on indent basis, often having various problems done by the seller (car dealer). The problem included in the transaction in sale-purchase transaction because the legal position of the customer (indenter) was weaker than the position of the businessman (seller). Another problem was the long period of indentation and sometimes exceeding the promised schedule The research method used was normative juridical approach by comparison between das sein (the facts found) and das sollen (which should be based on statutory regulations). The results of the study show that based on the problems that occur in new car sale-purchase transactions on indent basis, guided by Law on Customer Protection in Article 2, Article 7, Article 15, Article 16, Article 18 (1a), and Article 1338 verse (3) of Civil Code, legal protection for indenter car was required. The legal protection was prioritized in the aspect of equality, in line with the injustice between the seller and the buyer, especially in their legal positions. Furthermore, as a form of civil accountability for a businessman who had bad deed, in legally formal, Article 60 of Law on Customer Protection was imposed as a form of civil accountability and Article 62 of Law on Customer Protection as a form of criminal sanction.
\end{abstract}

Keywords: Legal Protection, Transaction, Sale-Purchase, Indent

\section{Introduction}

Sale and purchase are a form of transactions that are often done by the community. Usually, a sale and purchase agreement are made orally or in writing based on the agreement of the parties (seller and buyer). Article 1457 of the Civil Code define sale and purchase as "an agreement, with which one party is bound to submit a material, and the other party is to pay the price promised." In accordance with the principle of "consensualism," the sale and purchase agreement has been born at the time of the achievement of "agreement" regarding goods and prices. Once the two parties have agreed on the goods and price, a legitimate sale and purchase agreement is born. Once the agreement is born, it raises the rights and obligations between the parties; thus, the sale and purchase agreement is also called an obligatoir agreement, meaning that the sale and purchase does not transfer ownership rights but only distribute rights and obligations to both parties. 
However, at this time, the sale and purchase agreement has changed, especially the procedures or rules used. One of which is the use of the "indent system", a form of object development in the sale and purchase agreement for new goods in the future as stipulated in Article 1334 of the Civil Code. Sale and purchase agreement with a system like this can be done by ordering in advance or "indent".

"Indent system" is a command system (order) of a purchase by a seller to a buyer at a price set in advance for the intended specifications and carried out within a certain period. Meanwhile, the agreement and payment system depend on each car seller company set to the buyer. Generally, buyers order certain car models and types or brands with a down payment, while the method of payment is agreed in a Vehicle Order Letter. Sale and purchase agreement with indent system lead to the transfer of ownership of the object sold once the levering is done or handover from the seller (business actor) to indenter (customer).

Car sale and purchase with indent system does not end immediately after unit handover, but it still continues within a certain period. It is intended to anticipate that there is a discrepancy in the car received by indenter; in this case, the seller generally has specific accountability to the indenter. However, this accountability can be considered optimal but sometimes it can be also considered less or even not optimal.

Several cases regarding the discrepancy of cars ordered by indenter are as follows:

a. Discrepancy of the car ordered by indenter is a car with the brand "Chevrolet Spin LTZ type of diesel fuel", the car was in trouble (the body parts of the right and left front doors are different, in which the right door body was smashed in). This led the indenter to complain and feel dissatisfaction and considered that the buyer was cheated by the seller.

b. Car handover which is not in accordance with the order of indenter because unilaterally without consent of indenter, the seller handed over the wrong color which was different what intender ordered. The intender ordered metallic green car, but the seller handed over metallic dark blue car; it is completely different. In this case, the seller has defaulted (broken promise) for not delivering the car as ordered by indenter.

c. Discrepancy of the car ordered by indenter. This case started from a promotion carried out by seller through both printed and electronic media stating that the fuel oil consumption of Nissan March, according to their claims, is very economical to reach $18.5-21.8 \mathrm{~km} / \mathrm{liter}$. Triggered by the promotions in various media, consumers finally decided to buy Nissan March. After driving Nissan March car for several times, it turned out that the fuel consumption of Nissan March cars does not match what was promised before, so indenter felt dissatisfied and cheated, and then brought the case to the Consumer Dispute Resolution Agency (BPSK).

In addition to the three examples of dissatisfaction cases felt by indenter against the car sellers as described above, there is another problem which is no less interesting, i.e. indent period which takes too long and sometimes even goes beyond the promised schedule. At the time of the indenter receives the car, there has been an increase in car prices in the market. This condition makes the indenter confused, especially for those who have a limited budget.

The aforementioned examples show that their legal protection of car indenter is needed. However, it remains a problem since the car indenter is in a weak position of law compared to car seller. Therefore, intenders tend to be powerless to defend their rights because the intenders are weaker than the car sellers in terms of economics, technical knowledge and in taking legal actions through the courts.

Therefore, in an effort to provide legal protection to car consumers who feel disadvantaged, the agreement or consensus reached in the sale and purchase agreement needs to be reviewed. Based on the agreement referred to, the parties are legally bound to make 
achievements. Article 1234 of the Civil Code stipulates that achievement can be in the form of activities to do something, give something, or not do something. The seller is obliged to hand over the goods sold to the buyer, while the buyer is obliged to pay the price of the goods in accordance with what was agreed with the seller.

In fact, the author finds that the agreement between the two parties (buyer and seller) written in a standard agreement contains injustice. It is considered injustice since buyer has never been consulted or included in the preparation of the agreement clause. The dealer apriori determines all the contents of the agreement, both regarding the rights of the dealer and the buyer's obligations, risks, prices and authority of the parties. The dealer has also printed the agreement form, which will then be presented to the buyer for approval and signature.

In that position, there is no opportunity for the buyer to submit an offer, propose their rights, etc. The buyer has no choice but to agree to all the contents of the agreement that has been offered by the seller. If the buyer states that they disagree, the seller cannot force himself to add, subtract or change the contents of the agreement. Thus, the agreement to buy and sell new cars with indent system will never happen.

\section{Methods}

Research on the Legal Protection Aspects of Buyers in car sale and purchase with indent system used an empirical juridical approach, i.e. research on legal identification and legal effectiveness. The nature of this study utilizes descriptive analytical research, i.e. research that seeks to describe the research object in full, so that the state or condition of the object is clear. It is descriptive because the results of this study are expected to be able to provide a systematic, detailed and comprehensive picture of the legal protection in the aspect of buyers in car and purchase transactions with indent system. It is analytical because henceforth there will be an analysis to answer some of the problems that have been formulated before.

\section{Result and Discussion}

\subsection{Legal Protection Aspects For Car Indenter For Discrepancies Of Vehicles Handed Over By Car Dealer}

The sale and purchase agreement with indent system between the dealer and the buyers did not just happen, but it was driven by the motivation to make buying and selling transactions only. Initially, it began through a negotiation between the parties aiming to reach an agreement or consensus.

In general, the agreement was not made formally but through the conformity of the will of the parties (consensus) which later became known as the principle of consensual-ism, with the existence of conformity of the will, then the agreement was made.

The form of agreement or consensus reached in the sale and purchase agreement transaction with indent system was set forth in the written agreement. With this agreement, the parties are legally bound to make achievements. Article 1234 of the Civil Code stipulates that achievement can be in the form of activities to do something, give something, or not do something. The seller is obliged to hand over the goods sold to the buyer, while the buyer is obliged to pay the price of the goods in accordance with what was agreed with the seller.

Article 1458 of the Civil Code emphasizes that the sale and purchase agreement is considered to have taken place between the seller and the buyer if an agreement has been 
reached regarding the condition and the price of the goods even though the goods have not been delivered and the price has not been paid. This means that the sale and purchase agreement cannot be canceled unilaterally. In other words, sale and purchase agreement is applied if there is an agreement between the seller and the buyer regarding the goods and price, because the goods and prices are the essence of the sale and purchase agreement. If there are no goods to be sold, it is impossible to have sale and purchase transaction; on the contrary, if the goods which are the objects of the sale and purchase agreement are not paid for a price, there will be no transaction.

However, in reality, the author finds that the agreement between the two parties (buyer and seller) written in a standard agreement contains injustice. It is considered injustice since buyer has never been consulted or included in the preparation of the agreement clause. In this case, the dealer priory determines all the contents of the agreement, both regarding the rights of the dealer and the buyer's obligations, risks, prices and authority of the parties. The dealer has also printed the agreement form, which will then be presented to the buyer for approval and signature.

In that position, there is no opportunity for the buyer to submit an offer, propose their rights, etc. The buyer has no choice but to agree to all the contents of the agreement that has been offered by the seller. If the buyer states that they disagree, the seller cannot force himself to add, subtract or change the contents of the agreement. Thus, the agreement to buy and sell new cars with indent system will never happen.

Referring to the facts above, the sale and purchase agreement with indent system is classified into standard practice agreements. It is called standard agreement because it is not made through a balanced negotiation process between the two parties, but the agreement made by the car dealer provides the standard conditions in an agreement form that has been printed and is ready to be presented to the buyer for approval and signature. In this condition, the car dealer does not provide the opportunity or freedom at all for buyers to negotiate or have other offers.

Regarding to the author's analysis as stated above, Sudikno uses a term of standard contract to refer to standard agreements defined as agreements in which the contents are determined a priori by one party having a superior position to other parties. Meanwhile, Badrulzaman stated that the standard agreement is an agreement in which its contents are standardized and set forth in a certain form. Likewise, everything that happens in an agreement between a car dealer and a buyer in a car sale and purchase transaction with indent system is a standardized clause. However, there are some parts that have not been standardized including the brand, type, color choice, additional equipment, and number of units, car price, method and time of payment and time of unit handover. Although the clause contains an agreement between the two parties, the buyer has never been included in determining the contents of the agreement.

Regarding the validity of a standard agreement and the presence or absence of an element in the agreement, the weak party is forced to accept the contents of the agreement. In such circumstances, Sudikno said that "to determine whether or not there is an agreement in the standard agreement, it must first be seen the parts of the standard agreement." The standard agreement consists of three parts, namely the main agreement, additional or supplementary agreements, and standard terms.

In the main agreement and the additional or supplementary agreement section, there is an agreement; while in the standard conditions section, there is no agreement from the parties. However, the three parts constitute an inseparable unity. Therefore, it can be said that there is an agreement from the party making the agreement in a standard contract. 
If this is reviewed in theoretical juridical terms, the standard agreement does not meet the provisions of the law, but based on community needs; however, in reality, it can be accepted. Badrulzaman said that standard agreements have binding power based on habit (gebruik) prevailing in the community and trade." This is reinforced by the statement of Asser Rutten and Stein stating that "in accepting standard agreements by the community, the motivation is that the law functions to serve the needs of the community, and not vice versa". Since it tends to bind the purchaser, the Law No. 8/1999 on Consumer Protection (UUPK) regulates the issue of the inclusion of the standard agreement as stipulated in Article 18 of UUPK.

It was issued since standard agreements in practice are often misused for the sake of obtaining profits solely by the seller. It can be seen in the inclusion of an exoneration clause in each standard agreement. Exoneration clauses are clauses that intend to limit, reduce, or even transfer responsibility that should be borne by the producer or seller, but which is borne by other parties. Therefore, this clause is considered a clause which is burdensome for one of the parties to the agreement.

Related to the importance of protection of the buyer in an agreement with the car dealer party which has more dominant position, UUPK provides limits and controls in the use of the standard clause so as not to cause a very detrimental effect for the buyer.

Article 18 paragraph (1) letter (a) of the UUPK states that business actors in offering goods are prohibited from making and/or including standard clauses on every document and/or agreement that states the transfer of business actors' responsibilities or contains an exoneration clause. The provisions of letter (b) and so forth provide examples of responsibility transfer to other parties, e.g. business actors have the right to refuse the return of goods or money paid for goods and/or services purchased by consumers.

Such conditions, of course, hinder the right of a buyer to demand the cancellation of the sale and purchase agreement, known as actio redibitoria and the right to request a reduction from the purchase price paid or referred to actio quatiminoris as a result of hidden defects in material purchased by the buyer. Therefore, all unilateral actions taken by business actors/sellers are unfair.

The author considers that the prohibition in Article 18 paragraph (1) of the UUPK is actually intended to place the position of the purchaser equal to business actors based on the principle of freedom of contract, so as to create bargaining power balanced between the parties. For example, the buyer will make a purchase with the color, type, price, and delivery time which have been mutually agreed upon if the car dealer is able to provide the units within the next three months; and if the car dealer is unable to do so, the agreement is considered canceled and the purchase money is returned in full. To realize this condition, it takes courage to negotiate in order to obtain a balanced position; thus, the buyer's rights can be accommodated by the car dealer in a sale and purchase agreement. This is the main purpose of prohibiting the inclusion and/or making of standard clauses containing exoneration clauses in each document and/or agreement as mentioned in the explanation of Article 18 paragraph (1) of the UUPK.

This provision is emphasized in Article 18 paragraph (2) stating that standard clauses must be put in a place which is easily visible and can be read clearly and easily understood. The provisions contained in the article are motivated by the condition where the seller often includes exoneration clauses in standard agreements such as using unclear small letters, unattractive placement, and hard to notice or tends to make people ignore it, do not expect the buyer can read it, even to understand it. In other words, the inclusion of standard clauses that are deemed unnatural and ineffective for communicating them to the buyer and causing the buyer not to read them is prohibited. 
Referring to these conditions, there are indications of bad faith from the seller which is contrary to Article 7 of the UUPK. Even, the bad intention can be categorized as an attempt to fraud (Article 378 of the Criminal Code) by the seller to the indenter. Therefore, Article 7 of the UUPK affirms that business actors are required to have good faith in carrying out their business activities. In this study, it appears that good faith is more emphasized to business actors than to the buyer. This is due to the possibility of the buyer to incur losses for the seller starting when making a car purchase transaction. Conversely, the seller can do it at any time, from the time the units are produced until the units are in the hands of consumers.

Therefore, the agreement made by the parties must be implemented in good faith as affirmed in Article 1338 paragraph (3) of the Civil Code. Good faith, in this case, implies that the parties of the agreement are obliged to have proper actions. It means the car dealer and buyers in carrying out the agreement are prohibited from doing actions that cause harm to others, apply fairly and balanced, and heed the norms prevailing in society while maintaining mutual concern for the reasonable interests of each party. If the matters mentioned in Article 1338 paragraph (1) and (2) of the Civil Code are not fulfilled, the standard clause becomes null and void. Thus, it can be concluded that what determines the use of standard clauses by the seller is that they must be easily understood and understood by the buyer, so as not to cause harm to the buyer.

\subsection{Civil and Criminal Liability of The Car Dealer Against Indenter for The Discrepancy of The Car Ordered.}

Product liability is the legal responsibility of the person or legal entity that produces a product, (producer/manufacturer) and/or the party that sells the product and/or the party that distributes the product, including herein those involved in the commercial chain on the preparation or distribution of a product, the business people, agents and workers of the above business entity. Product liability can also be defined as a legal conception which is essentially intended to provide protection to consumers by freeing consumers from the burden of proving that consumer losses arise due to errors in the production process and at the same time the producers are responsible for providing the compensation.

The core of this definition is that the business actor is responsible for all losses arising from the results of the product or service. Article 19 paragraph (1) of the UUPK stipulates that business operators are responsible for providing compensation for damage, pollution, or losses suffered by consumers due to having goods and/or services produced or traded.

There are some reasons why the principle of responsibility is applied in the law of product liability as follows:

a. Among victims/consumers on the one hand and producers on the other hand, the burden of loss (risk) should be borne by the party producing/removing the defective/dangerous goods in the market.

b. By placing/distributing goods in the market, it means that the manufacturer guarantees the goods are safe and suitable for use; and if it is proven, the manufacturer must be responsible.

c. Without applying the principle of absolute responsibility, producers who make mistakes can be prosecuted through the process of successive prosecution. Implementation of strict liability is intended to eliminate this long process.

As in the relationship between businesses and consumers/car buyers in a sale and purchase transaction with indent system, this implementation will have legal consequences that are consciously desired by the parties. The legal consequences are not only subject to the applicable 
positive law, but also to the values of public order. This is based on the view that the term responsibility is more likely to embody ethical and moral values, while the term obligation is an embodiment of legal values or rules.

For this reason, looking at the responsibilities of business operators towards consumers is not enough in terms of business ethics. Besides, there may still be other perspectives from the social and individual sides, so it is natural that if someone expects more business actors to actively realize their responsibilities to consumers in order to carry out their role in the field of car trade, which of course without ignoring the obligations of consumers to the perpetrators effort. The claim of responsibility is also based on the fact that there is a loss suffered by a party as a result of a relationship between consumers and business actors in the utilization by consumers of goods and/or services produced by business actors. Along with the discrepancy with the car ordered by the buyer, the civil liability for business actors (car dealers) is regulated in the UUPK, especially Article 19 to Article 28.

In accordance with the implementation of the aforementioned articles for business actors who commit some form of irregularities, the Indonesian Consumers Foundation (YLKI) believes that the relationship of new car buyers with business actors (car dealers) cannot be said to be good. The main problem is that business actors often default on agreements or sale and purchase agreements, as well as lack of sense of responsibility to fulfill the rights of consumers, especially in terms of compensation. Therefore, YLKI mentions that there are several causes of defaults undertaken by business actors, including incompatibility between bidding and reality, internal aspects of business operators (car dealers) whose information is difficult to access by car buyers, standard agreements even though they have been banned by the UUPK, standard agreements in the norm of sale and purchase transactions, for example car buying and selling transactions with indent system, renegotiation with business actors, and bad faith in business. When there is a default, in which the business actor fails to carry out his obligations, the business actor still demands the buyer to pay his obligations, regardless of whether the buyer does not receive the rights according to the agreement.

Responding to the behavior of business actors who do not have good faith, car indenter has the right to report the matter to the relevant institutions on the legal basis, as follows:

a. The 1945 Constitution Article 5 paragraph (1), Article 21 paragraph (1), Article 21 paragraph (1), Article 27, and Article 33.

b. The Law No. 8/1999 on Consumer Protection (State Gazette of the Republic of Indonesia of 1999 No. 42 on the Supplement to the National Gazette of the Republic of Indonesia No. 3821).

c. The Law No. 5/1999 on Prohibition of Monopolistic Practices and Unfair Business Competition.

d. The Law No. 30/1999 on Arbitration and Alternative Dispute Resolution.

e. The Government Regulation No. 58/2001 on Supervision, Development, and Implementation of Consumer Protection.

f. Circular of the Director General of Domestic Trade No. 235/DJPDN/VII/2001 on Handling Consumer Complaints addressed to all Industry and Trade Office in the Province/District/City.

g. Circular Letter of the Director General of Domestic Trade No. 795/DJPDN/SE/12/2005 on Guidelines for Consumer Complaints Services.

With some of the legal basis mentioned above, the DKI Jakarta provincial YLKI seeks to summon the car dealer three times. However, in response, the car dealer countered the YLKI invitation by giving consumers an ultimatum. Then, YLKI recommended the buyer to submit the case to the Indonesian Ombudsman Commission and then to the Consumer Dispute 
Resolution Agency (BPSK). The Commission also tried to mediate between the two parties to the dispute. After several mediation efforts have not yet found a solution, the Ombudsman finally stated that this case was part of a consumer dispute regulated in the UUPK.

UUPK Article 45 paragraph (1) states that "Every consumer who is disadvantaged can sue a business actor through an institution tasked with resolving disputes between consumers and business actors or through the courts within the general court environment." A lawsuit against the issue of consumer rights violations needs to be done, where the position of consumers and business actors are equally balanced before the law. Consumers who feel their rights have been violated need to complain to the authorized institution. Consumers can ask the help of the Non-Governmental Consumer Protection Institute (LPKSM) in advance to ask for legal assistance or can directly resolve the problem with the Consumer Dispute Resolution Agency.

Consumers can also go to the Complaints Services sub-directorate at the Consumer Protection Directorate, Ministry of Trade. After the confirmation process is carried out, the official concerned will conduct an analysis of the problem in question, then clarify the consumer by asking for evidence and a chronology of the incident. After that, there will be a process of clarification be made to business actors. If the business actor refutes the accusation and there is no point of clarity, several steps will be taken such as mediation or conciliation. If there is no decision made after the aforementioned two steps, other two steps can be taken, 1) delegation to the Consumer Dispute Settlement Agency (BPSK), and 2) formally conducting juridical (court) channels, by prioritizing the application of Article 60 of UUPK as a form of civil liability for business actors. Whereas, the criminal liability for business actors is regulated in Article 62 of the UUPK. The imposition of criminal sanctions is applied because of the fact that there is an element of loss suffered by consumers due to a discrepancy of the car ordered.

\section{Conclusion}

The car sale and purchase with indent system which involves sellers (car dealer) and buyers (indenter) sometimes creates many problems including the time of car delivery the buyer is not in accordance with what was promised by the car dealer, and the car color provided sometimes does not match what was ordered and promised by the car dealer. Referring to UUPK in Article 2, Article 7, Article 15, Article 16, Article 18 paragraph (1a), and Article 1338 paragraph (3) of the Civil Code, legal protection for car indenter must be needed while prioritizing the equality aspect. As a form of civil liability for business actors who have bad faith legally formally charged /enacted Article 60 UUPK as a form of civil liability and Article 62 UUPK as a form of criminal sanctions. This is because there is an element of loss suffered by consumers with a discrepancy of the car ordered.

\section{Acknowledgments}

The author would like to thank and give an appreciate to the Head of Semarang State University for providing a facility to join International Conference in ICILS 2020.

\section{References}

[1] Subekti, R., and R. Tjitrosudibio, Kitab Undang-Undang Hukum Perdata (Jakarta: Pradnya Paramita, 2009) 
[2] Subekti, R., Hukum Perjanjian (Jakarta: Intermasa, 2008)

[3] 'Aspek Yuridis Perjanjian Jual Beli Dengan Sistem Indent Untuk Obyek Barang Yang Akan Ada', 2008 <http://justitiaomnibous.blogspot.com/2008/08/aspek-yuridis-perjanjianjual-beli.html>

[4] Warsito, Hermawan, Pengantar Metodologi Penelitian: Buku Panduan Mahasiswa (Jakarta: Gramedia Pustaka Utama, 1992)

[5] Mertokusumo, Sudikno, Mengenal Hukum: Suatu Pengantar (Yogyakarta: Liberty, 2010)

[6] Subekti, R., Aneka Perjanjian (Bandung: Citra Aditia Bakti, 1995)

[7] Badrulzaman, Mariam Darus, Aneka Hukum Bisnis (Bandung: Alumni, 1994)

[8] Siahaan, NHT, Hukum Konsumen: Perlindungan Konsumen Dan Tanggung Jawab Produk (Jakarta: Panta Rei, 2005)

[9] Supriatiningsih, Eka, 'Perlindungan Hukum Terhadap Hak Konsumen Dalam Industri Perumahan Menurut Undang-Undang Nomor 8 Tahun 1999 Tentang Perlindungan Konsumen.', Jurnal Hukum De'rechtsstaat, 2016.

[10] Shofie, Yusuf, Perlindungan Konsumen (Bandung: Citra Aditya Bakti, 2003). 